\title{
The Practice Research on Cultivating PE Majors' English Competence based on English Sports Films
}

\author{
Liyang Zhang, Chunmei Yu* \\ Public Foreign Language Education College, Beihua University, No \\ 3999 Binjiangdong Road Jilin City, Jilin Province, 132013
}

\begin{abstract}
English film with its vivid language, intuitive picture of the image to stimulate student interest in learning English movies to help students familiar with the British and American accents to help students improve their listening comprehension and consolidate the students learn English grammar! Syntactic knowledge, and so provide a true language data. According to the characteristics of the English majors, it is found that English majors of PE majors are related to the development of their English. According to this feature, the students of English majors should take corresponding measures to improve their English learning ability.

Keywords: practice, research, PE majors, English competence, English sports films, carrier.
\end{abstract}

\section{Introduction}

In the multimedia teaching environment today, how to effectively carry out college English teaching has become a major English teachers face a major issue and challenge, the community increasingly high quality requirements for students, reflected in English learning, is to ask students to the traditional Written English to the real language to use up, which requires students to not only have the basic knowledge of English, but also should be fluent in oral communication skills and balanced knowledge of English culture in order to achieve the requirements of learning English language, in this English language teachers need to have the 
following qualities to meet the challenge: a strong basic skills in English language, listening, speaking, reading, writing, translation skills, verbal ability; understand the theory of education, students understand the Understanding of Chinese and Western culture, cultural content can penetrate into English teaching; master modern educational technology, multimedia and other computer-aided teaching methods can be used; constantly updated teaching philosophy, followed by the theory of applied linguistics development.

English movies allow students to learn English from the soundtrack to learn English as a native speaker how to use the native language. For many students learning English, beautiful melodies and wonderful British and American film lines and lyrics conducive to the students in a relaxed state of mind to learn the language. English film "for students to create a fetter from the mother tongue I mobilize the learners eyes, ears, mouth, brain and even the whole body and mind to respond to the three-dimensional learning context. The information in the film through the visual, auditory, Operation, transmission to the brain center, and establish a signal link, on this basis to improve the language ability in those who watch in the memory of the film in the dialogue, and real life, once the scene coincides with the scene, will induce the brain Rapid response and accelerated memory, the formation of the language after the deepening of the sense of language can be seen in English as a teaching aid means of the feasibility and superiority.

\section{The current situation of English learning of sports major students}

$75.19 \%$ of the students think that the teaching level of teachers is normal, $13.33 \%$ of the students think it is good, $11.45 \%$ think that is very poor. This shows that the level of teaching teachers have not yet been recognized by sports students. The use of Chinese or English to explain a few, and the use of English and Chinese combined accounted for the vast majority. This is conducive to the students to improve their listening and speaking, the use of English teaching, can provide students with a better English atmosphere, to develop English thinking and reasoning ability are good. On the other hand, students are also taught in accordance with their aptitude, because the English level of students in sports is generally not high, the full use of English teaching, teaching effect will be greatly reduced.

English learning time is the decisive factor to improve English performance, without a certain amount of time, the English level can not be improved [2]. PE students spend less time on English learning every day, and more than $50 \%$ of them spend less than 1 hour per day learning English. 1-2 hours a day to learn very little, only about $30 \%$, more than 2 hours a day to learn even less, and usually only to cope with operations.

Sports professional teaching is divided into theory and technology teaching, relative to other professional, physical education students of the theoretical 
course hours is small. So there are plenty of spare time can be used to learn English, but the actual number of students learning English is too small, which may be related to training time and physical fatigue and other factors, but more important reason may be missing in the sports majors Did not form a strong atmosphere of English learning.

The importance of English test certificates to students is self-evident, and the passing rate of exams is equally important for schools. The importance of the two important additions is more important, so the school also has the necessary management of English communication. According to the interview, these four colleges and universities do not allow students to apply for the national English four or six in advance, for this provision, $62.22 \%$ of the students that is unreasonable, $21.85 \%$ answer is not clear, only $15.93 \%$ of students think it is reasonable. The vast majority of students want the school to provide more English exam opportunities to promote their English learning. 54.07\% of the students answered moderate, $33.34 \%$ of the students answered too little, only $12.59 \%$ of the students answered too much. This shows that a considerable number of students feel that lack of time, which shows that students of sports have recognized the weakness of their foundation, hoping to increase their time to improve their English.

\section{The influence of English movies on PE students' English ability}

The use of English movie lines and vocabulary to help students understand the words and sentences, and ask students to complete the sentence to answer. The teacher extracts the phrase or sentence from the film and allows the student to select the same phrase or sentence on the answer sheet. The teacher asks the student to answer the question after reading the film. Students can directly answer the questions according to the film plot; students with their own point of view to answer questions raised by teachers to develop students' attention and understanding.

English film characters are using the normal speed to speak. This makes the students accustomed to and can understand the spoken English commonly used in the abbreviation, weakening and other pronunciation features, gradually familiar with the British and American accents. Students come into contact with the pure voice, the natural speed, from different countries of the English country's accent and style, out of the "English language for students to write a sense of flu ... After watching a complete English film students, Students are asked to understand the social background of the film and to write a video to help students learn the grammar, syntax, lexical and tense knowledge and improve their writing skills.

Teachers can according to the film content, let the students play the characters in the original sound film. English film role-playing, students' ability of thinking, speaking, use of English to express ideas constantly improve the ability of students to overcome the introverted personality, to carry out mutual learning. 
English film role-playing, improve student pronunciation accuracy, students find language sense; review classroom knowledge of English, students apply their knowledge, knowledge and action. Teachers of the students' education is not only knowledge-based, but also a complete personality education and comprehensive quality improvement.

\section{Suggestions on improving English proficiency in physical education students}

The motivation of PE students to learn English is external motivation. The process of learning English is a passive and passive process. The study of English is mainly for the purpose of finding a job and examining the graduate students, which has certain influence on their English proficiency. The enthusiasm of PE students in learning English after class is not high, most of the students did not participate in English Corner and other English activities. After school English learning time and reading very little, there is no good English learning atmosphere is that they did not pass the English proficiency test the most important reason. The biggest obstacle for English majors to study English is the listening, followed by the spoken English. The main way they learn English is the classroom and teaching materials. The quality of classroom teaching is not very high, the teaching focus of one-sided, reading, listening and speaking are not subject to teachers and students attach great importance. First, pay attention to students' interest in learning English. Improve their English learning motivation and interest, so that students learn English motivation from "to me" into "I want to learn." As the basis of sports students is not solid, teachers should be encouraged in the classroom-based approach, the difficulty of teaching content should not be too large, it should be gradual, so that students experience learning English sense of accomplishment, to overcome the anxiety of students learning English, Learning English as a burden to help them play a psychological advantage, to overcome the psychological disadvantage, really learn English. The second is to strengthen the construction of style of study, and enhance afterschool English learning. Strengthening the Construction of Study Style and Enhancing English Study after Class are the Key to Improve the English Level of PE Majors. From the investigation of the status quo of PE students, it is found that the most important factor restricting students' English proficiency is that they do not have the habit of learning English. Most physical education students have little time to read extracurricular English, they do not have enough reading and listening practice, and they do not participate in English activities, which results in their hearing and speech disorder. Interviews learned that some sports college leaders attach great importance to student learning English, Jianghan University, Wuhan Institute of Physical Education and the College of English over four or six students have credits and material rewards. In addition, you can also open the English learning experience exchange, invite English learning excellent students to introduce their own experiences, and guide students to make good use of spare 
time, such as supervising students night classes and early reading. Most of the students of sports are not allowed to apply for the examination of the national English proficiency test. Most hope to increase the English class.

\section{Conclusion}

Teachers use the English original film as college English listening and speaking and reading and writing teaching to make up the information, to a large extent to help students improve English listening and review the classroom learning English knowledge. English movies to improve students' interest in learning English, familiar with the British and American accents, to understand Englishspeaking countries. In the use of English films as teaching to make up for information, teachers should carefully choose teaching video content. English teachers to study and use of teaching theory, continue to explore suitable for Chinese foreign language teaching methods.

\section{Acknowledgements}

The research work was supported by [2015] 75: Education and Science Project, Jilin Contract. NO. 104115003

\section{References}

[1] Qian Yuling. On the New Citizens' Junior High School English Learning Situation and Countermeasures. Middle School English, 55(12), pp.68-70, 2011

[2] Hu Meng. Investigation and Analysis on the Current Situation of English Learning of Deaf Students in Zhejiang Province. Journal of Hubei University of Education, , 8 (5), pp.87- 91, 2013

[3] Zhang Guang-hua. The Investigation and Analysis of the Current Situation of English Learning of Higher Vocational Students. Journal of Science of Education (Middle Ages). 12(10), pp. 18- 20, 2012

[4] Xu Jinjin, Zhao Lin. Medical students of English learning status quo questionnaire analysis report. Inner Mongolia Education (Vocational Education Edition). 9(6), pp.58- 61, 2011

[5] Chen Xu. Higher vocational students of English learning situation analysis and countermeasures. Journal of Jiamusi Education Institute, 8(4), pp.85-87, 2014 